\title{
Ars Electronica Festival 2017 - relacja
}

\section{Ars Electronica Festival 2017 - intelligent solutions - a report}

\section{Streszczenie}

Niniejszy artykuł jest próbą zrelacjonowania najnowszych rozwiązań z zakresu techniki i sztuki przedstawionych na festiwalu Ars Electronica - które, w ocenie autora, są warte zaprezentowania szerszej publiczności. Ponadto przedstawione zostało wydarzenie o skali światowej, które zorganizowano wzorowo, a na potrzeby festiwalowe zaadaptowano kluczowe obiekty w centrum miasta.

\begin{abstract}
This article is an attempt to relate the latest solutions in the field of technology and art presented at the Ars Electronica festival - which in the author's opinion are worth presenting to a wider audience. In addition, the event was presented on a global scale, which was organized exemplary and for which the important buildings in city center was adapted.
\end{abstract}

Słowa kluczowe: sztuka, technologia, sztuczna inteligencja, festiwal sztuki i technologii

Keywords: art, technology, artificial intelligence, art and technology festival

Wszyscy wiemy, że sztuka nie jest prawdą. Sztuka to kłamstwo, które pozwala uświadomić sobie prawdę, tę przynajmniej, jaką dane nam jest zrozumieć.

Pablo Picasso

Można by rzec, że Linz to takie miasto, w którym wszystko się udaje, gdyż zrealizowano tam wiele dobrych pomysłów, jak np. z zakresu architektury - Solar City, które zostało zaprojektowane przy współdziałaniu sławnych biur architektonicznych, realizujących zrównoważoną wizję osiedla przyszłości. Ponadto w ostatnich latach nad Dunajem powstało wiele nowoczesnych i wysoko ocenianych za swoją jakość obiektów miejskich. Miasto Linz położone jest w górnej Austrii i liczy zaledwie ok. 200 tys. mieszkańców, a rozwija się głównie dzięki zlokalizowanemu $\mathrm{w}$ regionie przemysłowi metalowemu, maszynowemu oraz chemicznemu. Z pewnością ma ono wiele atutów i niesamowity potencjał, lecz nie jest wielomilionową metropolią przyciągającą nowych mieszkańców. Chociaż to niewielkie miasto, to czy można je zakwalifikować jako Smart City? Czy można przypisać niewielkiej strukturze urbanistycznej wiele cech inteligentnych? Niniejszy artykuł opisuje dobre praktyki zastosowane lub wizjonerskie rozwiązania proponowane dla nowoczesnych i inteligentnych miast. Dominującym tematem publikacji jest opisane wydarzenie Ars Electronica Festival, który prezentuje corocznie szerokiej publiczności wiele innowacyjnych rozwiązań, bardziej lub mniej zaawanso-
We all know that Art is not truth. Art is a lie that makes us realise truth. at least the truth that is given to us to understand.

Pablo Picasso

Linz - it can be said that it is a city in which everything is successful, as many good ideas have been implemented there, for instance - in terms of architecture - the Solar City, which has been designed as a part of a mutual cooperation of famous architectural offices, implementing a vision of a housing estate of the future. Furthermore, many modern urban structures, highly regarded for their quality, have been built along the Danube in recent years. The city of Linz is located in upper Austria and has a population of only 200 thousand inhabitants and its development is mostly based on the metallurgic, machine and chemical industry that is based in the region. It surely has many advantages and an extraordinary potential, but it is not a multi-million metropolis attracting new residents. Even though it is not a large city, can we still qualify it as a Smart City? Can we ascribe many intelligent qualities to such a small urban structure? This article describes good practices that were implemented in or visionary solutions that are being proposed for modern and intelligent cities. The chief subject of the publication is a report on the Ars Electronica Festival event, which presents many innovative solutions - that are more or less 
wanych technologicznie, ale posiadających potencjat, który w przyszłości może być kluczem do budowania efektywnych i inteligentnych infrastruktur do użytkowania przez nowoczesne społeczeństwa informacyjne.

Obecnie zauważyć można, iż pewne słowa, powszechnie występujące, są często nadużywane, jak np. przymiotnik: inteligentny, w odniesieniu do miasta, telefonu, domu, osiedla, czy innych przedmiotów. Stosując to okreslenie producenci próbuja nadać im lepsze przymioty. Wszystkie wspótczesne produkty wydaja sie być sztucznio zarekomendowane przez marketing jydaja się być sztucrnie zarekomendowáe przez marketing

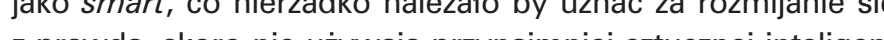

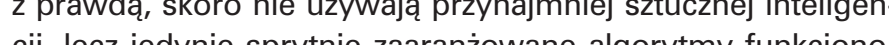
cjl lecz jedyie sp wania. In

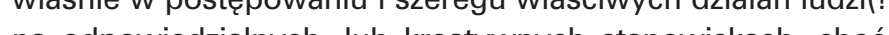

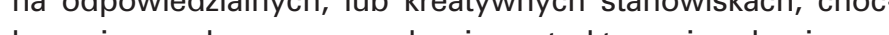
by zwiazanych np. 2 zarzagdzanem strukturami zurbanizowanymi lub ich fragmentami, połączonych we wspólny system wymiany oraz wykorzystania informacji - danych, które służa polepszeniu ich funkcjonowania, użytkowania etc. To właśnie nietypowe (mniej powszechne) myślenie jest kluczowe w realizacjach, dzielach, pomystach i mstalacjach zaprezentowanych podczas festiwalu. Często, jak pokazują karty historii, większy postęp cywilizacyjny można było uzyskać przez rozwój myśli, niż rozwój jedynie technologii, na zasadzie powielania, które wykorzystują zdobycze know how po to, aby przez wytwarzanie dostarczyć produkt - generować zysk. Chciałbym zaznaczyć także istote wielu współczesnych trendów i wydarzen uwzględniających ich społeczną rolę w kształtowaniu technologii, polegająca, z jednej strony na zaangażowaniu osób i specjalistów wielu branż, jak również tematów, programu skierowanego dla dzieci oraz młodzieży, celem wcześniejszej adaptacji zachęty młodych pokoleń do używania oraz rozwijania technologii przyszłości. Inteligencja to także sięganie po nowości nie tylko w przemyśle czy usługach, ale także generowanie nowych narzedzi, formatów ekspresii dzieta artystycznego, czy nawet futurystycznych wizji, teorii naukowych. Ars Electronica Festival 2017 - "Artificial Intelligence - The Other I." festiwal jako platforma', odbywający się w dniach 07-11.09.2017 roku w Linz, Austria - to międzynarodowe wydarzenie cykliczne organizowane po raz 38 od 1979 roku. Szerokiemu gronu odwiedzajacych organizatorzy prezentuja wiodace technologiczne i zaawansowane prace, wybrane z całego świata, z zakresu innowacyjnych myśli, rozwiązań, z całego swiata, z zakresu innowacyjnych myśli, rozwiązan,
czy też technologii powiazanych z wieloma dziedzinami sztuki. Inteligentne rozwiązania wpisują się w nowoczesne tendencje Smart City w odniesieniu do skali miasta - regionu, jak również domeny codziennego życia. Obecnie $w$ sferze mediów i elektroniki doświadczamy czegoś, co mogło by zostac okresione synonimem eksplozja kambryjska ${ }^{2}$ - co, poprzez analogię, polegać ma na pojawieniu się wielkiej ilośc przeróżnych form z zakresu mediów cyfrowych. Współcześni teoretycy i futuryści nierzadko prezentują swoje wizje przyszłości za pomocą sztuki lub rozwazan naukowych, w których nasze marzenia i obawy są jednocześnie materializowane. $\mathrm{Cy}$ frowośćc $c^{3}$ rozprzestrzenia się szybko i koncentryczne, czasem szybciej, niż mogłoby się kiedykolwiek wcześniej wydawać. technologically advanced, and which can, in the fuintelligent inf a key to the builuing of efrective and mation societies - every year.

It can currently be observed that some common words, like the adjective intelligent, are often overused in relation to cities, phones, homes, housing estates or other items in an attempt to ascribe better qualities to them. Most modern products marketing which should often be consider far from the truth, as they do not even use artificia intelligence, but only cleverly arranged functionaity algorithms. The intelligence that I mention here should rather be seen in the actions and a number of positive efforts by people (!) in responsible or creative positions or who are associated with, for instance, the management of urban structures or their fragments, which are interconnected into a common system of sharing and using information - data that serve to improve their functioning use, etc. It is the atypical (less common) type of thinking that is key in the built projects, ideas an installations that are presented during the festival. Oftentimes, as history often shows, greater civilzational development can be achieved through the development of thought rather than the sole development of technology, using the principle of repetition, which use know how-related achievements in generate profit I would also like to highlight the generate profit. I would also like to highlight the consider the public role in the shaping of technology, which is based, on the one hand, on the involvement of people and specialists from on the fields, as well as subjects, in addition to a programme directed at children and the youth, mean to convince the younger generations to adopt and develop technologies of the future on the other. Intelligence is also searching for novelties not only in services or industry, but also generating new tools and formats of expression for works of art, or even futuristic visions or scientific theor

Ars Electronica Festival 2017 - "Artificial Intelligence - the Other I.", a festival as a platform, whic took place between 07-11.09.2017 in Linz, Austria is an international cyclical event that was organised for the 38th time. The organisers present advanced works which are leading in terms of technology, se lected from all over the world, ranging from innovawith mony, solutions or technologies associated visitors. Intelligent solutions fit into modern Smat City tendencies in relation to the scale of the city the region, as well as the domain of everyday life In the sphere of the media and electronics we are currently experiencing something, which can be described, using the term Cambrian explosion' ${ }^{1}$ which, by analogy, is based on the appearance of an immense number of various forms in terms of digital media. Modern theorists and futurists of ten present their visions of the future using art or
Pomimo iż poziom dojrzałości technologii, czy oprogramowapojawiają się nowe mozzliwości i rozwiazania dezaktualizujące poprzednie), a przeróżne relacje w mediach też nie tworzą dobrego wizerunku prognozowanej przyszłości, powstaja śmiate wizje wykorzystania postępu w budowaniu lepszego życia Od trzech lat z rzędu zagadnienia wirtualnej rzeczywistości determinuja tematyke festiwalu angażując społeczeństwo do partycypacil w doświadczeniu i kreacji nowej rzeczywistosci partycypacji w doswiadczeniu i kreacji nowej

Festiwal Ars Electronica jest miejscem prezentacji niezliczonej ilósi nowych form z zakresu sztuki, elektroniki ni , elektroniki, maszy mistości, zarządzani dzis baz i Grodowsk samouczacych siej, Jak rowniez nowe sposoby prosrodowisk sa re grom in również eksperymentem na swoj temat. $Z$ jednej strony jest to otwartosc na publicznosce, a z drugiej skupienie uwagi na awanga dowych dzielach medianych, jako isscie wydarenia. Festiwal animacji jest w obecnym roku osobnym bytem wpisującym się w organizację glównego eventu. W kooperacji z prywatnym Uniwersytetem Anton Bruckner w Linz, uruchomiona została muzyczna edycja festiwalu z zakresu elektronicznych instalacji dźwiękowych. W tym roku debiutowa równiez panel dyskusyjny w postaci sympozjów, warsztatów oraz cyfrowej galerii sztuki, zogniskowany wokół tematyki teatru, a przede wszystkim zastosowania w nim cyfrowyc mediów. Wydarzenia główne i towarzyszące organizują platformę do rozwoju nowych modeli biznesowych oraz marketingu, w zmieniającej się kulturze społecznej. Nowością jes też pojawienie się sztuk tanecznych na styku interakcji człowieka z maszyna, wykorzystujących aspekty behawioru urzadzeń cyfrowych. Festiwal sztuki, technologii swoją misją obja monitorowanie i pośredniczenie w rozwoju technologiczny i społecznym:

Smarty City Forum forum miast inteligentnych" (II. 1) to kon-

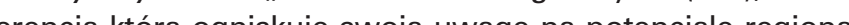

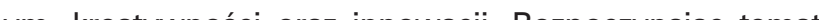
pan, kuture in a Nutshell (przyszlośc w pigude) - omatyke pan, kr future in a Nutshell (pryszlosc w pigu nologich nogiczr badawcza Spaxels), którego gospodarzem był Futurelab $b^{5}$ dotyczyl tema

Sympozja, warszlaty, lekcje mialy na celu prezentację technologii i dyskusji o edukacji, a odwiedzający mogli nabyc umiejętności DIY, w zakresie elektroniki, aby samemu two rzyć i hakować (dostosowywać do swoich potrzeb) roboty, komputery, czy oprogramowanie na cele swobodnych im plementacji technologii w kulturze, zgodnie z gtównym tematem "The other I". W panelu How cultures shape technology" poruszano spoleczne i kulturalne aspekty rozwoju domeny sztucznej inteligencji wraz z artystycznymi możliwościami uczenia (się) maszyn.

Wystawy w swym programie realizują dwa podstawowe cele: projekty artystyczne i techniczne powstałe na bazie badań naukowych oraz przedstawiające ekspresję artystyczną scientific dissertations, in which our dreams and ears are simulaneously materialised. The digita spreads fast and in a concentric manner, sometimes faster than we could have ever imagined. Although the level of the maturity of technology or software has not been fully achieved yet (because new possibilities and solutions that make the previous ones obsolete are constantly appearing) an various media reports also do not paint a good using progress in order to build a better life afe being developed. The problems of virtual reality have dominated the subject of the festival for three consecutive years, involving culture and the public to participate in the experiencing and creation of a new reality in an era of widely accessible digital media.

The Ars Electronica festival is a place of the presentation of an innumerable amount of new forms ronics, machinery and other forms of virtual (digital) reality, city management and associated subjects. Research and development egarding robotics and computers, self-earning Nironments, as well as new methods of proloT currently being some of the greatest breakhroughs ${ }^{3}$. The event is also an experiment on itsell. On the one hand it features openness to the public, while on the other it is a focus on avant-garanimation festivat was a seperate entity this vear. included in the organisation of the main eaert In cooperation with the private Anton Bruckner University in Linz, a musical edition of the festival was established, featuring electronic sound instalations. This year also saw the debut of a discussion panel in the form of symposiums, workshops and a digital arts gallery, focused on the subject of theatre, but mainly on its use of digital media. The main and accompanying events organise a platform for the development of new business and marketing models in a changing social culture. Ane Ane meeting point between the interactions of man and cestival has in-

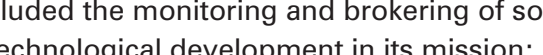

Smart City Forum [ill.1] is a conference that focuses its attention on regional potential, creativity an Il, the organisers proposed a new outlook on the latest technological trends. The Spaxels Research Initiative panel, hosted by Futurelab $b^{4}$ focused the subject of drone vehicles and swarm logistics. The symposiums, workshops and lessons were aimed at presenting technology and discussing education, while visitors could gain DIY skills ${ }^{s}$ in terms of electronics so that they could create and hack robots, computers or software for the purposes of the free implementation of technology
across culture, in accordance with the main sub- 


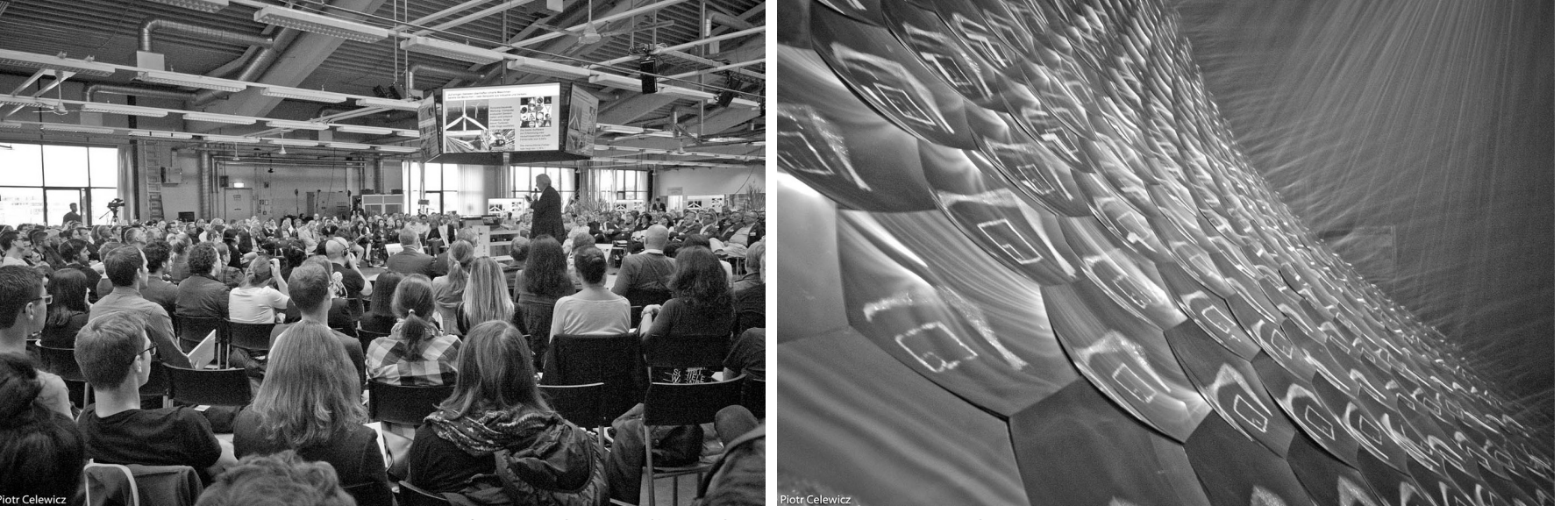

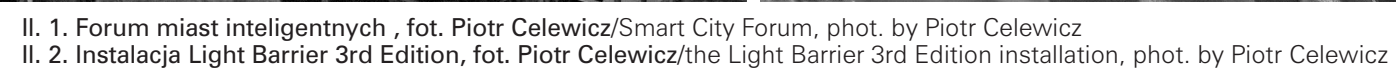

technologii. Wystawa dotyczyła nagrodzonych prac, wybranych z pośród nadesłanych z całego świata na festiwal, któnych z pośród nadesłanych z całego świata na festiwal, któ-
re prezentują projekty badawcze i rozwiązania prototypowe re prezentują projekty badawcze i rozwiązania prototypowe
a nawet wizjonerskie. Dominującym nurtem tematycznym a nawet wizjonerskie. Dominującym nurtem tematycznym
w wystawianych pracach są zagadnienia: człowiek, maszyna w wystawianych pracach są zagadnienia: człowiek, maszyna
dane - algorytmy behawioralne środowisk komputerowych dane - algorytmy behawioralne srodowisk kompute rowy
i robotów; sztuczna inteligencja oraz maszyny jako protezy; sztuka mediów - pomiędzy naturalną a sztuczną inteligencją; dylematy dotyczące esencji człowieczeństwa w maszynie i o kreacji bez kodu (cyfrowego); dzieło medialne pomiędzy sztuczną a prawdziwą inteligencją wraz z warsztatami: jak zacząć uczyć maszyny zagadnień sztuki; nauka i sztuka w za-
łożeniach programowych Komisji Europejskiej oraz sztuczna intymność - czy człowiek może pokochać robota? Festiwal muzyczny - wystawił koncerty cyfrowej muzyki i próby łączenia instrumentów akustycznych z robotyka. Ars Electronica Campus - prezentował osiągnięcia w zakresie realizacji programów edukacyjnych z całego świata, spójnych $\mathrm{z}$ tematyką konferencji.

Cyber arts prix2017 (II. 2), - to wystawa nagrodzonych prac z zakresu cyber-art-u oraz Instalacji artystycznych.

Time's up w muzeum sztuki wspótczesnej Lentos, - wystawa nowe fali artystów kolektywu time's up koncentrujacego swoja twórczość na happeningach oraz transformacąago swoja tworzescich na artystyczna zmieniła nabrzeże rzeki w idylliczną zatokę.

Vr lab - virtual space - mieszczące się w Ars Electronica cenVr lab - Virtual space - mieszczące sie W Ars Electronica cenprojekty w wysokiej rozdzielczości $8 \mathrm{k}$ w rzeczywistości rozprojekty $w$
szerzonej.

Media art (sztuka mediów) - to instalacje artystyczne w Katedrze Mariackiej przy Herrenstrasse - instalacje mediów cyfrowych i happeningów, instalacje taneczne oraz wielkoformatowe media na fasadach.

Poniżej opisane zostały projekty, które wywarły na autorze artykułu największe wrażenie:

LightScale II - Mariendoom- instalacja ta jest faworytem wydarzenia i była polecana przez organizatorów. Interaktywna i jednocześnie kinetyczna rzeźba autorstwa Uwe Rieger - Uniwersytet Auckland - Lab for Digital Spacial Operations Nowa Zelandia, została umieszczona w Katedrze Mariackiej w Linz. Gigantycznych rozmiarów struktura symbolizująca ssaka walenia - LightScale Il umieszczona została w głównej hali bazyliki zaj- ject, called "the other I". The panel: How cultures shape technology? discussed the social and culturficial intelligence, along with the artistic capabilities of machine learning.
Ticial intelligence, alortistic capabilities The exhibitions in this programme work towards two main goals: artistic and technical projects the artistic expression of technology. The exhibition featured prize-winning works selected from among festival entrees from all over the world, which presented research projects and prototypical or even visionary solutions. The dominant theme of the exhibited works was the subjects of man, machine vironments and robots; artificial intelligence and machines as prostheses; the art of the media - between natural and artificial intelligence; the dilemmas of the essence of humanity within the machine and on creating without (digital) code; a media work workshops: how to start to teach machines abou art: science and art in the programmatic assumptions of the European Commission and artificial intmacy - can a human love a robot?

The music festival featured concerts of digital ments with robotics.

The Ars Electronica Campus - presented achievements in terms of the carrying out of educational line with the subject of the conference.

The Cyber arts prix 2017 [il..2] - is an exhibition of prize-winning cyber-art works and artistic installations.

Time's up at the Lentos museum of modern art - an exhibition of the time's up new wave artists' collective who have concentrated their activity on happenings and transformations over the past couple
of years at the habitat. The exhibited artistic instolof years at the habitat. The exhibited artistic instalThe VR lab - virtual space - housed at the Ars Elecexpanded reality projects using media projections. church near Herrenstrasse - digital media instatlarge-format media on building's façade. and data - behavioural algorithms of computer en music and attempts at combining acoustic instruprogrammes from all over the world that were in tronica centre, presented digital $8 \mathrm{k}$ high resolution Media art - were artistic installations at St Mary's church near Herrenstrasse - digital media instal-
lations and happenings, dancing installations and mując ok. połowę jej długości. Płynie ona przez wirtualny oceinterakcji w środowisku, czyli ciemnej j pełnej ciszy przestrzen kościoła. Ze względu na gabaryty dzieła, katedra wydawała się być najlepszym miejscem na jego prezentację. Doświadczenie dotyku (napędzania) kinetycznej instalacji rozpoczyna impresje eksploracji świata danych. Rzeźba ta w półmroku świątyn oświetlana jest projekcja video-mappingu\& z rzutników treśc medialnych, podobnie jak inne elementy struktury budowi medianych, podobnie jak inzerza ej wnętra. Lighiscale II wzbogaconą o adekwatne dzwięk i pozwa przenieść myśli widza w odlegte krajobrazy. Cyry pozwala przeniesc mysli widza w odlegle krajobrazy. Cyfry wzory gementach katedry sa mezmiaru oceanu

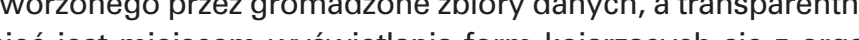
siec jest miejscem wyswiellania form kojarzacych się z organicmani morskimi. Dzjelo buduje niesamowite napiecie i jest niecodziennym przeżyciem pozwalającym na konteplację chaotycznego świata danych cyfrowych

Singularity - instalacja autorstwa Uwe Rieger, Carol Brown - łączy taniec i dane cyfrowe z muzyką, architekturą i interaktywnym mappingiem. Dwuetapowy performance prezentuje trójwymiarową konstrukcję holograficznej dynamicznej prze strzeni wchodzącej $w$ interakcje $z$ ruchem tancerza zmienialąc swoją formę podziały i wielkość. Zastosowane urządzenia pozwalają na projekcję laserową, kształtującą się w chmurz dymu, jako ekspresję świetlną będącą, wynikiem geolokalizacji tancerza oraz jego pozycji, które dalej kształtowane sa poprzez algorytm systemu na ekspresję świetlną. Pojawia sie gra i transformacja fizycznego ruchu $z$ wirtualnym $w$ przestrzeni architektonicznej. Wraz z uzupełniającą muzyką elektroniczną tworzy pełne relacji środowisko w performansie umiejscowionym w rzeczywistości rozszerzonej. Zaawansowana technologia służy przedstawianiu nowych zjawisk wykorzystywanych w spektaklach na pograniczu realnego i wirtualnego świata.

Rockprint (II. 3) - to projekt badawczy oraz urzadzenie oparte Rockprint (II. 3) - to projekt badawczy oraz urządzenie oparte na zasadzie funkcjonalnej drukarki 3d wykorzystujące nietypowy materiał jak kamien, stosowany do budowy nasypów kolejowych oraz sznurek jako spoiwo dla powstającej struktury i wskrzeszenia arystyczn go wyrazu w produkcji maszy Research - grupy badawczej na uczelni ETH w Zurichu, prowadzonej przez światowej sławy architektów.

Zwycięski i nagrodzony główną nagrodą projekt na wystawie Zwycięski i nagrodzony główną nagrodą projekt na wystawie, z zakresu prac badawczych i wdrożeniowych, prezentuje nietypowe podejscie do myslenia o nośności dwóch materiałów. Za sprawą połączenia dwóch rożnych materiałów o określonych cechach, otrzymać można zupełnie inne cechy nie wy stępujące osobno wcześniej. Kamien i sznurek są elementam tworzącymi struktury o nowych cechach jak nośność i unikalna organicznosc formy, a takze o oryginalnym wyrazie kreaci artystycznej. Robot służący do zsypywania kamieni oraz parametry sznurka okrązającego i utrzymującego są określan w oprogramowaniu sterującym i prowadzą do uzyskania konkretnych cech nowoformowanego obiektu. Trwałość gwarantuje spinająca skały lina, więc i w każdej chwili usuwając ją,
Below is a description of projects that have made a particular impression on the author:

Lightscale II - Mariendom - this installation was the favourite of the event and had been recommended by the organisers. The interactive and simultaneously kinetic sculpture by Uwe Rieger - from the Auckland University Lab for Digital Spatial Operations, New Zealand, was placed at St. Mary's Cathedral in Linz. The gigantic structure pleced in the main hall of the bailica occupying around half of its length. It flowed through a vint al ocean of digital data, which materialised in the form of human interactions in an environment of the dark and silent space of the church. Due to the size of the work, the cathedral seemed as the best location for its presentation. The experience of touch (setting the kinetic installation in motion by pushing model) begins the impression of the exploration of the world of data. The sculpture, residing in the dark interior of the temple, was lit up by a video-mapping projection ${ }^{6}$ from multimedia projectors, similarly to other elements of the structure of the building - its interior. LightScale // enriched by adequate sounds of the natural surroundings of the depths of the sea, brought to mind associathe and allowed a viewers thoughts to travel faraway landscapes. The digits and graphical patterns projected onto the pillars and other elements mind a heciations with the expan of the oceont formed by datasets, and the transparent network was a place of the displaying of forms that brought to mind marine organisms. The work built an extraordinary tension and was a unique experience that allowed one to contemplate the chaotic world of digital data.

Singularity - an installation by Uwe Rieger and Carol Brown - combined dance with digital data and music, architecture and interactive mapping. The two-stage performance presented a three-di(n) space that interacted with the dancer's motion, changing its form, division and size. The devices an werestion was the ref smoke as an expression of light that as the result of the geo-location of the dancer and er a appears a play and a transform of light. There motion with a vitual one, within an ar physical space. Along with the accompanying electronic The it it created an environment that was full relations within a performance placed in an augmented reality. Advanced technology was used in the presentation of phenomena used in spectacles at the border of the real and virtual world. Rockprint [il. 3] - is a research project and a device based on the principle of a functional $3 d$ printer the uses the atypical material that is stone, whic is used to build railway escarpments, as well as
string used as a binder for the structure that is be- 


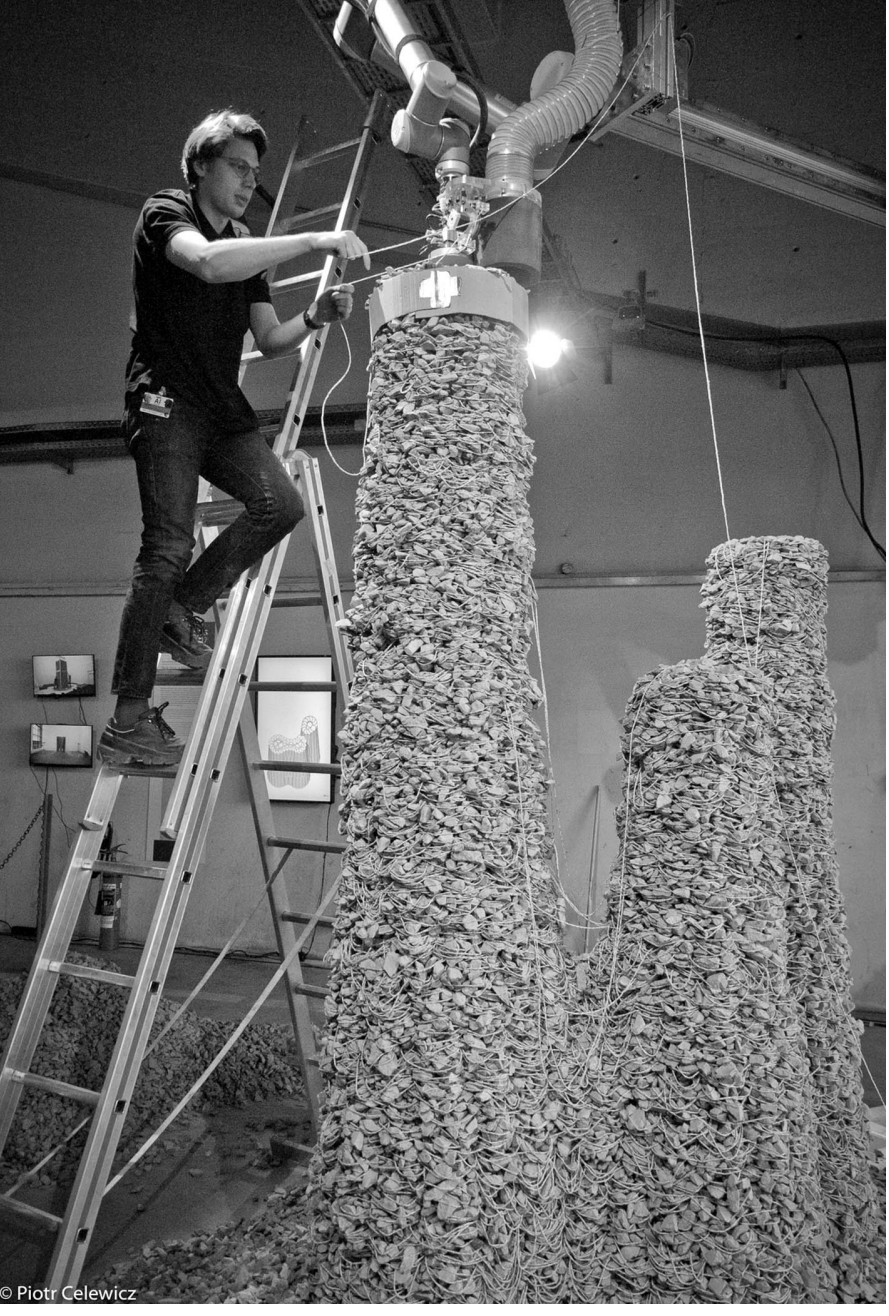

II. 3. Instalacja Rockprint, fot. Piotr Celewicz/the Rockprint installation, phot.
by Piotr Celewicz

można w prosty sposób zdezintegrować formę do czynników pierwszych, które ją budują.

Hackathon BR41N.IO oraz ET 65 [II. 4-5], to kolejny interesujący projekt firmy badawczej BR41N.IO wywodzącej się z Uniwersytetu Technicznego w Graz w Austrii. G.tec medical engineering $\mathrm{GmbH}$ skupia inżynierów, programistów, lekarzy, projektantów, artystów i designerów, którzy intensywnie współpracują jako zespół interdyscyplinarny. Planują i produkuja własne, w pełni funkcjonalne, słuchawki z interfejsem dúz wha w mózg-komputer, do sterowána np. droch, robotem lub ortezą motopyczną. Proteza, kóra pozwoli odczytac nasze myśl za pomocą fal mózgowych generowanych przez myśli i mikro impulsy elektryczne pojawiające się na powierzchni głowy
w określonych rejonach mózgu jest elementem integrującym w określonych rejonach mózgu jest

zywy organizm z cyfrową maszyną. Urządzenia te zastosowano w projekcie o nazwie ET 65 w kooperacji z Wacker Neuson, Ars Electronica Futurelab oraz firma architektoniczną any:time. Ponieważ stanowisko firmy wydawało się ciekawe, poprosiłem o możliwość przetestowania na sobie działania takiego systemu z kierowaniem zadaniowym pracą 6-tonowej koparki przygotowanej specjalnie do tego celu. Podczas montowania hełmu z sensorami na mojej głowie rozmawiałem z autorami prototypu o zasadach działania, które poniżej pragnę przestawić. Urządzenie interfejsu montowane jest bezpośrednio na głowie, a sensory poprzez płyn przewodzą impulsy elektryczne, łącząc się z miejscami głowy odpowiedzialnymi za procesy myślowe. Następnie system ing created and to resurrect artistic expression in machine production. It was created by a group of scientists from Gramazio Kohler Research - a research group from the ETH University in Zurich, which is led by world-famous architects.

The main prize-winning project at the exhibition in the research and development category, it presented an atypical approach to thinking abou to combining two different materials with specific qualities, we can obtain completely other qualities that have not been observed before on their own. Rock and string are elements that create structures with new characteristics like load-bearing capacity and a unique organic character of form, as well as an original manner of artistic expression. The robot that serves to place the rocks and the parameters of the string that surrounds and holds them are defined in control software and lead to the obtaining of particular qualities of a newly formed object. The string, that binds the rocks together, ensures durability, that we can easily disintegrate the form to its

The BR41N.IO Hackathon and ET 65 [ill. 4-5] were another interesting project by the BR41N.IO research company that hails from the Graz Technical University in Austria. G-tec medical engineering $\mathrm{GmbH}$ is a group of engineers, programmers, medical professionals, designers and artists who plan and produce their own fully function. They phones with a therr own be used to control a drone, robot or motor prosthesis. The interface, which will make it possible to read our brain waves generated by thoughts and electric micro-impulses that appear on the surface of the head in specific regions of the brain. That prosthesis is an element, which integrates a living organism with a digital machine.

These special devices were used in a project named $E T 65$ founded in cooperation with Wacker Neuson, Ars Electronica Futurelab and the any:time architectural company. Because the company's booth seemed interesting I asked to test ou the operation of the system and to personally control the tasks performed by a 6 -ton excavator tha had been prepared specifically for this purpose. At the beginning the sensor helmet was being $p$ on $\mathrm{my}$ head. I asked the authors of the prototype about the principles of its operation that I wanted on the head and sensors conduct electric impulses through a liquid, connecting to spots (skin) on the head that are responsible for thought processes. The following presentation shows me encephalogram graphs and application, which can interpret received data. Afterwards, the system reads the mind. The calibration involved performing a series of repeatable actions and thinking about images that appeared in certain places on a monitor. The counting of such images resulted in brain activity that was registered by the computer. The entire

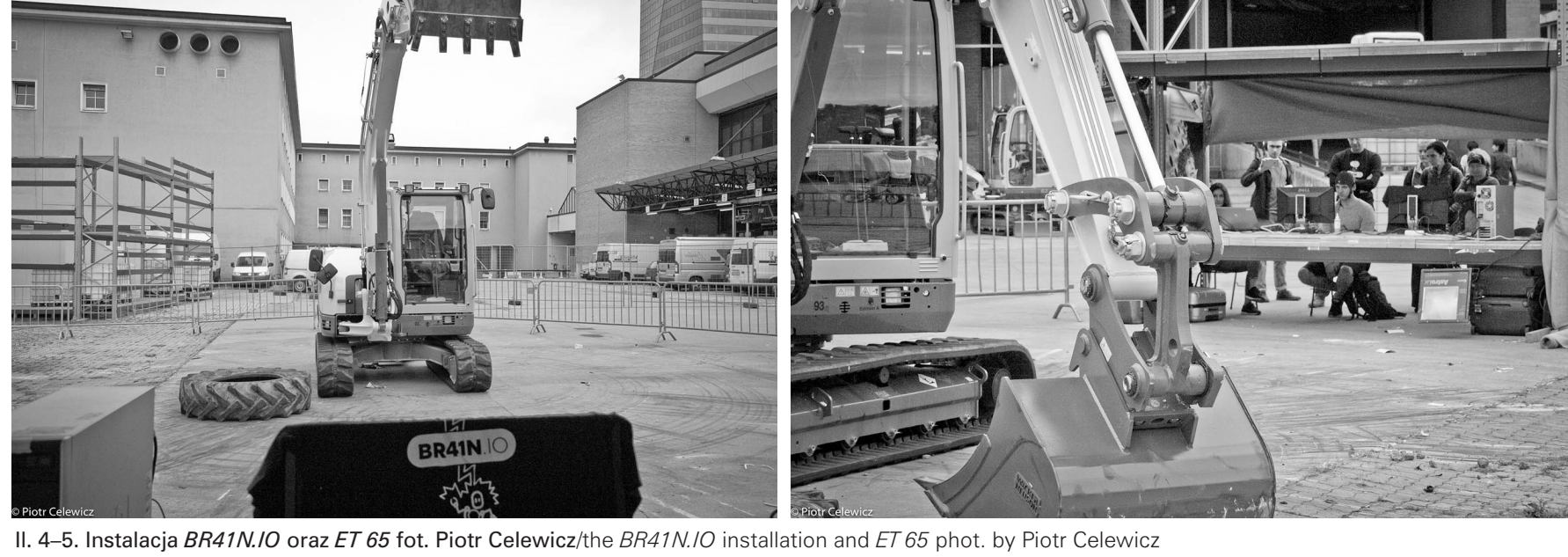

odczytuje myśli za pomocą kilku wykresów encefalografu. Kalibracja polega na wykonywaniu pewnych powtarzalnych czynności i myśleniu o obrazach pojawiajacych się $w$ danym miejscu na monitorze. Liczenie takich obrazów skutkowało majscu na monitore. Liczenie takich obrám skukowa wy wymagała dużego skupienia. Następnie $w$ komputerze zostala uruchomiona aplikacja, służąca do sterowania zadaniowe go pracą koparki, jak np. obrot ramienia o 30 stopni, podniesienie lub opuszczenie ramienia o określoną wysokość ok $1,5 \mathrm{~m}$, a nawet ruch lyzik. Po krotkin wyjaśnieniu zasad dzialania aplikacji, przeszedłem do meritum i koncentrowałem się myślowo na czas ok. 5 sekund, na konkretnych ikonac wyświetlanych na monitorze i symbolizujących dany ruc urządzenia a koparka wykonywała moje polecenia na skutek procesów myślowych. Było to bardzo ciekawe doświadczenie pozwalające przekonać się, iż obecnie dysponujemy technologią przedstawianą przez wizjonerów i dającą wiele możliwości. Jakkolwiek rozwiązania te nie sa jeszcze bardzo dojrzałe i wymagają dopracowania, niemniej pozwalaja juz dziś znajdowac dla nich nowe zastosowania.

Ars Electronica Festival 2017 to znakomicie przygotowane wydarzenie pozwalające na ogląd nowości z branży elektronicznej, które sukcesywnie beda coraz bardziej powszechne. Od kontaktu z interfejsem zabawek, aż po sterowanie pojazdem - koparka budown kontrowa pa zamo pomazmyśli Koleino poprzez edukcie która nazonocą ludzkich event posob testującyc na sztuce, medlectu rzenie znalo wa Ponacto festwa by wydarzenc taktów oraz lužnych rozmów w kuluarach. Przy okazji przechadzania się po wystawie trafitem na grupe naukowców z Wiednia zajmujacych się tematyką Blockchain. Jest to bardzo aktualna tematyka dotycząca nowego paradygmatu budowy bezpiecznych systemów cyfrowych wykorzystywanyc $w$ tworzeniu systemu monetarnego dla nowego wirtualnego pieniądza bitcoin, a także dla uwiarygodniania w sieci www oraz kształtowania bezpiecznych środowisk zarządzania danymi. Frekwencja świadczy o popularności wydarzenia w światowym rankingu.

Festiwal Ars Electronica skutecznie angażuje całe miasto jako platformę wydarzenie. W roku 2017 na główną siedzibę wy- procedure required a lot of focus. Afterwards, an application was ran on the computer that was used to control and operate the excavator, e.g. to rotate of its arm by 30 degrees, lift or lower the arm by a given height, e.g. around 1,5 $\mathrm{m}$ and even to move the bucket. After a short explanation of the principles of the operation of the application, began the core task and, after concentrating $\mathrm{my}$ toughts for around 5 seconds on specific icons

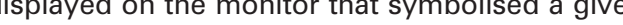
my wy orders thanks only to thought processes. It We a very interesting experience allowing me to 列 which provides shown to us by visionaries and solutions are not fully mature and alhough these work, they allow us to find new applications for hem even today.

Festival 2017 was an excellently ies from the electronics ind possible to see novelfully be becoming more and more common. From contact with a toy interface all the way to operating a vehicle - a construction excavator controlled by called a Hackathon - an event based on a meeting of a group of persons who test code and who hack and rebuild devices, and, at last, art, digital media visitors, which can be called a success. While walking on the exhibition grounds I came across a group of scientists from Vienna who worked focuses on the construction of safe digital sysfems used in the creation of a monetary system for the new bitcoin digital currency, as well as for verication on the linternet and to shape safe data speaks of the popularity of the event on the globel the entire city as a platform of the event. In 2017 the Postcity building, which is located in the direct vicinity of the circulation station - the hall of ve former train station, was selected as the main
venue, which the reception, the main events, exhibitions, lectures, installations and concerts human thoughts. Followed by education that was and city management, the event has found many on Blockchain. It is a very topical subject, which

The Ars Electronica festival effectively involves 
znaczono budynek Postcity znajdujący się w bezpośrednim sąsiedztwie dworca komunikacji - czyli hali dawnego dworca kolejowego, w którym zlokalizowana została recepcja, główne wydarzenia, wystawy, wykłady, instalacje, koncerty. Drugim ważnym miejscem ekspozycji była Katedra Mariacka przy Herrenstrasse. Dalej w stronę północy obiektami festiwalowymi były: Ok Center for contemporary Art oraz Movimento, gdzie zlokalizowano instalacje artystyczne oraz festiwal animacji. W pomieszczenia Uniwersytetu Sztuk Pięknych i Designu wraz z Muzeum Lentos zlokalizowano wystawy czasowe, okazjonalne, wpisujące się w program. $\mathrm{Na}$ przeciwnym brzegu rzeki znajduje się Ars Electronica Center (zbudowane specjalnie jako całoroczna wizytówka festiwalu oraz centrum prezentacji innowacyjnych technologii, gdzie oprócz stałej ekspozycji wystawiano instalacje rzeczywistości rozszerzonej i sztuk medialnych. Panele związane z edukacją muzyczną odbywały się najdalej na północ w prywatnym uniwersytecie Anton Bruckner. Wszystko to bliżej lub dalej zlokalizowano wzdłuż głównej osi miasta północ-południe. Udział w festiwalu jest interesujący nie tylko dla naukowców, pasjonatów techniki czy specjalistów, ale także dla każdego niezależnie od wieku, ponieważ spektrum tematyki oferowanej dla widzów jest tak ogromny, iż prawdopodobnie zaspokoi każdą ciekawość.

\section{PRZYPISY}

${ }^{1}$ Ars Electronica Festival 2017 "Sztuczna inteligencja - Inny ja."

2510 mln lat temu, na początku okresu kambru, wyznaczająca początek ery paleozoicznej, pojawienie się niezliczonej liczby organizmów i form „życia”- opotraktowano w artykule jako analogie do rozwoju i wielości wystepowania dzie i formatów medialnych, aplikacji pomysłów wykorzystanych przez inteligentne media i urządzenia cyfrowe. https://pl.wikipedia.org/wiki/Eksplozja_kambryjska

3 Świat mediów cyfrowych, aplikacji oraz urzadzeń inteligentnych.

${ }^{4}$ IA- sztuczna inteligencja; VR - rzeczywistość wirtualna; AR - rzeczywistość rozszerzona; loT- Internet i urządzenia

${ }_{5}^{5}$ Futurelab - jednostka podległa Ars Electronica Center w Linz.

6 Zrób to sam

7 Jak kultura kształtuje technologię.

8 Technologia projekcji treści wizualnych na obiektach które stają się trójwymiarowym ekranem a w tym przypadku jeszcze ruchomym. Pozwala nadać nowych wizualnych cech przedmiotom.

\section{LITERATURA}

[1] Przewodnik po wydarzeniu

[2] Oö Nachrichten Spezial 01.09.2017 - wydanie specjale w gazecie lokalnej

źródła internetowe: (stan na 30.11.2017):

https://www.aec.at/ai

https://pl.wikipedia.org/wiki/Eksplozja kambryjska

http://dfab.arch.ethz.ch/web/forschung/e/0/0/0/0.html

http://www.br41n.io/Linz-2017

https://www.aec.at/ai/en/et65/

https://norbertbiedrzycki.pl/blockchain-trzeba-o-nim-wiedziec/

link do filmu przygotowanego przez autora Piotr Celwicz

https://www.dropbox.com/s/mpeguwfp4i7ypdt/AE-2017-Linz-PiotrCelewicz. mov?dl=0 were organised. The second important place of the exhibition was the St. Mary's Cathedral near Herrenstrasse. Further to the north, the Ok Centre for contemporary Art and the Movimento building were turned into festival venues, featuring artistic installations and animation festivals. The rooms of the University of Fine Arts and Design, as well as the Lentos Museum housed temporary exhibitions, which were in line with the programme. At the opposite side of the river is the Ars Electronica Centre (which was built specifically to function as a year-round showcase of the festival and a centre of the presentation of innovative technologies, where, apart from a permanent exhibition, augmented reality and media arts installations were exhibited. Panels associated with musical education took place in the northernmost building, at the private Anton Bruckner University. All of this was more or less near to the main north-south axis of the city. Participation in the festival is interesting not only to scientists, technology enthusiasts or specialists, but also to everybody else regardless of age, because the spectrum of the subject on offer for the viewers is so immense that it will probably satisfy everyone's curiosity.

\section{ENDNOTES}

1510 million years ago, duirng the beginning of the Cambrian period, which marks the beginning of the Palaeozoic period, the appearance of an innumerable amount of organisms and "life" forms - was referred in the article to the analogous development and multitude of works and media formats, applications and the ideas used by intelligent media and digital devices.. https://pl.wikipedia.org/wiki/Eksplozja kambryjska 2 The world of digital media, applications and smart devices, ${ }^{3} \mathrm{Al}$ - artificial intelligence; VR - virtual reality; AR - augmented reality; IoT - Internet of Things

${ }^{4}$ Futurelab - a unit of Ars Electronica Centre in Linz

${ }^{5}$ Do it yourself

${ }^{6}$ The technology of projecting visual content on structures that become a three-dimensional screen, and in this cases a moving one. It allows bestowing new visual qualities to objects.

\section{BIBLIOGRAPHY}

[1] Event guide

[2] Ö̈ Nachrichten Spezial 01.09.2017 - special edition of a local newspaper

online sources: (retrieved on 30.11.2017):

https://www.aec.at/ai

https://pl.wikipedia.org/wiki/Eksplozja_kambryjska http://dfab.arch.ethz.ch/web/forschung/e/0/0/0/0.html http://www.br41n.io/Linz-2017

https://www.aec.at/ai/en/et65/

https://norbertbiedrzycki.pl/blockchain-trzeba-o-nim-wiedziec/

Link to a film prepared by the author

https://www.dropbox.com/s/mpeguwfp4i7ypdt/AE-2017-Linz-PiotrCelewicz.mov?dl=0 